\title{
REGENERASI RUMPUT LAUT Kappaphycus alvarezii(Doty) MELALUI INDUKSI KALUS DAN EMBRIO DENGAN PENAMBAHAN HORMON PERANGSANG TUMBUH SECARA IN VITRO
}

\author{
Emma Suryati dan Sri Rejeki Hesti Mulyaningrum \\ Balai Riset Perikanan Budidaya Air Payau \\ Jl. Makmur Dg. Sitakka, Maros, Sulawesi Selatan 90511 \\ E-mail:emmasuryati@yahoo.com
}

Naskah diterima: 22 Januari 2009; Diterima publikasi: 1 April 2009

\begin{abstract}
ABSTRAK
Regenerasi rumput laut Kappaphycus alvarezii dilakukan dalam rangka penyediaan benih yang bermutu dan mempunyai keunggulan melalui induksi kalus dan embrio dengan penambahan hormon pertumbuhan yang diintroduksi ke dalam media kultur yang dapat memacu induksi kalus dan penebalan pigmen rumput laut. Media kultur yang digunakan adalah media Conwy padat dengan penambahan agar 0,8\%-1,6\%. Hormon perangsang tumbuh yang digunakan untuk memacu pertumbuhan kalus dan filamen embrio yaitu IAA (Indol acetic acid), kinetin, dan auxilin dengan konsentrasi berkisar 0,4-1 mg/L. Embrio yang dihasilkan merupakan anakan yang mempunyai sifat yang sama dengan induknya. Sintasan dan perkembangan embrio yang paling baik yaitu dengan penambahan IAA dengan konsentrasi $0,4 \mathrm{mg} / \mathrm{L}$ pada media padat. Pembentukan anakan dilakukan dengan mengiris embrio dan menumbuhkan pada media cair yang diperkaya dengan hormon yang sama. Pemeliharaan anakan pada media kultur dilakukan hingga mencapai ukuran $2-3 \mathrm{~cm}$.
\end{abstract}

KATA KUNCI: hormon tumbuhan, embrio rumput laut, $K$. alvarezii, in vitro

ABSTRACT: Regeneration of seaweed Kappaphycus alvarezii (Doty) by in vitro induction of callus and embryo using plant growth regulator. By: Emma Suryati and Sri Redjeki Hesti Mulyaningrum

Regeneration of seaweed Kappaphycus alvarezii was done to provide high quality seed through callus and embryo induction using plant growth regulator which was introducted to the culture medium. This growth regulator can stimulate the callus induction procces and thickening the seaweed pigment. Applied medium culture was agar medium with 0.8\%-1.6\% concentration enriched with Conwy and the applied growth regulators were IAA (Indol acetic acid), kinetin dan auxilin with 0.4-1 $\mathrm{mg} / \mathrm{L}$ concentration range. Resulted embryo has the same characteristics with the stock. The best survival rate and embryo growth was IAA treatment with $0.4 \mathrm{mg} / \mathrm{L}$ concentration. Formation of embryo was done by transferring them from solid medium to the liquid one with the same growth regulator treatment. The nursery of the seed in culture medium was carried out until it has reached $2-3 \mathrm{~cm}$ in size.

KEYWORDS: growth regulator, embryo of seaweed, $K$. alvarezii, in vitro

\section{PENDAHULUAN}

Rumput laut $K$. alvarezii merupakan salah satu komoditas unggulan penghasil karaginan yang banyak dimanfaatkan dalam industri kertas, tekstil, fotografi, pasta, dan pengalengan ikan. Peningkatan usaha budidaya ditingkat petani memacu 
peningkatan sediaan benih yang unggul baik kualitas maupun kuantitasnya. Penggunaan benih yang berulang pada satu lokasi dapat mengakibatkan penurunan kualitas karaginan maupun pertumbuhan yang ditandai dengan pertumbuhan yang kurang maksimal. Salah satu upaya yang telah dilakukan antara lain yaitu melalui teknik kultur jaringan menggunakan eksplan dari tallus rumput laut dengan media kultur untuk makro algae telah berhasil dilakukan (Amini et al., 1995; Suryati et al., 2007). Penelusuran variasi genetik dan karakteristik rumput laut juga telah dilakukan untuk meningkatkan produksi serta koleksi varitas unggul yang nantinya dapat digunakan sebagai induk. Berdasarkan hasil penelitian yang telah dilakukan beberapa tahun terakhir pada kultur jaringan rumput laut dan analisis genetik rumput laut $K$. alvarezii, diperoleh informasi mengenai media yang baik pada perbanyakan secara invitro (Suryati et al., 2002) serta karakter genetik dari beberapa varietas rumput laut $K$. alvarezii yang ada di Indonesia pada umumnya (Parenrengi et al., 2004).

Pada tanaman tingkat tinggi regenerasi tanaman secara in vitro dapat dilakukan melalui induksi tunas (organogenesis) atau induksi embrio somatik (embriogenesis somatik). Teknik kultur jaringan yang dapat menginduksi embrio somatik lebih diinginkan karena dapat berasal dari satu sel pada jaringan somatik yang perkembangannya serupa dengan embrio normal. Regenerasi melalui jalur embriogenesis somatik mudah diregenerasikan menjadi embrio bipolar, yaitu mempunyai dua kutub yang langsung sebagai bakal tunas dan akar pada tanaman tingkat tinggi (Damayanti et al., 2007).

Teknik perbanyakan benih melalui kultur jaringan melalui induksi kalus dan perbanyakan embrio telah berhasil dilakukan pada tanaman tingkat tinggi, dengan penambahan hormon perangsang tumbuh baik golongan auxin maupun sitokinin. Pada induksi kalus dan pembentukan embrio pada rumput laut telah dilakukan oleh Reddy et al. (2003) menggunakan NAA (Naphtalen acetic acid) dan BAP (Benzil amino purin) untuk memacu pembentukan embrio pada tallus rumput laut yang dapat berhasil dengan baik. Namun masih ada hormon perangsang tumbuh jenis lain yang memiliki sifat yang hampir sama yang dapat dieksplor pemanfaatannya pada kultur dan induksi kalus rumput laut seperti IAA, auxilin dan kinetin yang sering digunakan pada induksi kalus dan pertumbuhan embrio pada tanaman tingkat tinggi secara in vitro (Hendaryono et al., 1994).

Pada regenerasi rumput laut $K$. alvarezii melalui induksi kalus dan embrio perlu diketahui pengaruh dan konsentrasi hormon yang dapat digunakan serta pemanfaatan lainnya pada kultur jaringan rumput laut terhadap pembentukan embrio, serta sintasan embrio pada media padat dan cair serta pemeliharaan anakan hingga mencapai ukuran yang dapat diaklimatisasikan di lapangan.

\section{BAHAN DAN METODE}

\section{Persiapan Eksplan}

K. alvarezii dikumpulkan dari kebun petani di Kabupaten Takalar dibawa ke Laboratorium Balai Riset Perikanan Budidaya Air Payau (BRPBAP) dalam wadah yang ditutup dengan kain yang dibasahi dengan air laut. Tallus rumput laut yang sehat dari penyakit dan bersih dari lumut dipotong sekitar $5 \mathrm{~cm}$ dan dibersihkan dengan air laut yang disaring dengan membran filter. Untuk inisiasi dan penyesuaian pada kondisi laboratorium, eksplan yang telah dipotong dikultur pada air laut steril yang diperkaya dengan pupuk Conwy. Untuk menghilangkan diatom digunakan $\mathrm{GeO}_{2}(10 \mathrm{mg} / \mathrm{L})$ ditambahkan untuk semua media kultur selama 2 minggu pertama kultur. Fluktuasi cahaya yang digunakan yaitu gelap: terang $=12: 12$ jam.

Fragmen yang dipilih untuk kultur jaringan, disterilkan dengan metode sterilisasi permukaan (Polne-Fuller \& Gibor, 1984; Huang \& Fujita, 1997). Explants dibersihkan dengan sikat di bawah mikroskop, kemudian dimasukkan ke dalam 0,5\% deterjen cair dalam air laut steril selama 10 menit, kemudian dengan betadin $2 \% \mathrm{w} / \mathrm{v}$ ) di dalam air laut steril selama 3 menit untuk menghilangkan mikroba permukaan, kemudian disterilisasi menggunakan campuran antibiotik $3 \%$ di dalam media kultur Conwy selama 2 hari. Untuk menguji sterilisasi dikonfirmasi dengan menumbuhkan pada media agar dan disimpan pada inkubator.

\section{Induksi kalus dan Embrio}

Embrio rumput $K$. alvarezii diperoleh melalui fragmen yang telah disterilkan selama 24 jam, dicuci dengan air laut steril lalu diiris kurang lebih 4-5 mm. selanjutnya dikeringkan dengan kertas saring steril untuk menghilangkan 
cairan dan lendir pada saat memotong. Kemudian diletakkan di atas media kultur bacto-agar-solidified Conwy medium dengan volume $20 \mathrm{~mL}$ dan kepadatan agar $0,8 \%(\mathrm{w} / \mathrm{v})$ sebanyak 15 eksplan pada setiap cawan. Setelah 2 minggu, kalus terbentuk pada bagian epidermis yang mengandung pigmen, kemudian menebal dan membentuk filamen, lalu dihitung pertumbuhan kalusnya. Setelah 30 hari kemudian dipindahkan ke dalam media kultur yang baru. Setelah 2 bulan kalus embrio dipindahkan ke dalam media kultur yang baru dengan kondisi yang sama.

\section{Media Kultur yang Digunakan dengan Kepadatan Agar, Cahaya, dan Hormon Perangsang Tumbuh}

Untuk memperoleh induksi kulit yang tebal, pertumbuhan eksplan yang konsisten dan optimal, perlu standarisasi media kultur dengan komposisinya seperti pupuk yang digunakan, kepadatan agar, pengatur pertumbuhan, dan fluks foton intensitas cahaya. Media kultur diperkaya dengan pupuk pada budidaya makroalgae seperti PES 1/20, Conwy, dan SSW. Untuk mengetahui kebutuhan cahaya fluks yang optimal, maka digunakan intensitas cahaya dengan kisaran 500, 1.000, 1.500, dan 2.000 lux, sedangkan untuk kepadatan agar digunakan $0,6 \% ; 0,8 \%$; $1,0 \%$; dan $1,2 \%$, hormon pengatur tumbuh yang digunakan antara lain IAA, auxilin, dan kinetin dengan konsentrasi 0,4-1,0 mg/L.

Terjadinya induksi kalus ditentukan setelah 2 minggu pemeliharaan dan akan terbentuk embryogenik dan somatik embriogenesis pada bagian pigmen atau kulit bagian luar. Setelah 60 hari pemeliharaan, kalus perlu dipindahkan dengan mengiris embrio dengan hati-hati, pada media kultur yang baru dengan kepadatan 0,4\% bacto-agar atau 0,6\% agarose. Embrio yang diiris dipindahkan ke dalam cawan petri yang berisi $20 \mathrm{~mL}$ medium kultur dengan gelling agar rendah, dengan kondisi pemeliharaan yang sama seperti di atas. Pada pemeliharaan perlu diperhatikan untuk menghindari pergantian temperatur yang terlalu drastis. Pergantian media kultur dilakukan dengan interval 40-45 hari.

\section{Pemeliharaan Anakan Rumput Laut pada Media Cair}

Embrio somatik kecil yang dihasilkan dari kalus yang berkembang menjadi anakan, diiris dengan pisau steril, dibilas dengan air laut steril kemudian dimasukkan ke dalam botol kultur yang berisi $20 \mathrm{~mL}$ media kultur yang diperkaya dengan hormon perangsang tumbuh dengan konsentrasi tertentu. Botol kultur ditempatkan pada shaker dengan kecepatan 100 rpm selama 1 bulan, kemudian pindahkan ke dalam botol nonaxenic, hingga tumbuh sampai anakan mencapai $3-5 \mathrm{~cm}$. Selama kultur micropropagule, media diganti dengan interval mingguan.

\section{HASIL DAN BAHASAN}

Sintasan eksplan rumput laut Kappaphycus alvarezii yang ditumbuhkan pada media padat yang diperkaya dengan beberapa macam pupuk memperlihatkan bahwa media padat yang diperkaya dengan pupuk Conwy (Liao et al., 1983); memberikan sintasan yang paling tinggi hingga mencapai $93 \%$, dan yang paling rendah yaitu media kultur yang diperkaya dengan pupuk Miguel (Gambar1). Berbeda dengan Reddy et al. (2003), dalam risetnya menggunakan media kultur padat yang diperkaya dengan PES untuk pembentukan induksi kalusnya.

Media kultur yang diperkaya dengan pupuk Conwy memperlihatkan pertumbuhan dan pembentukan induksi kalus yang paling baik, eksplan dapat bertahan hidup dan memperlihatkan pertumbuhan embrio pada lapisan epidermis yang mengandung pigmen. Hal ini kemungkinan disebabkan karena kebutuhan nutrien dari eksplan dapat dipenuhi dan dapat memacu pertumbuhan rumput laut tersebut walaupun ditumbuhkan pada media padat. Pupuk Conwy baik digunakan pada pertumbuhan mikroalgae dan nutriennya dapat dimanfaatkan pada kultur makroalgae seperti Kappaphycus alvarezii.

Kepadatan media agar berpengaruh terhadap sintasan eksplan yang dikultur secara invitro, penyerapan nutrien pada media padat sangat dipengaruhi oleh porositas dan kekenyalan dari media tersebut sehingga nutrient dapat terserap dan dapat dimanfaatkan oleh eksplan yang dikultur. Hasil pengamatan sintasan eksplan rumput laut pada media kultur yang dipadatkan dengan agar berkisar $0,6 \%$ $1,2 \%$. Pada kepadatan 0,6\% eksplan mengalami kematian setelah 3-4 hari yang diawali dengan pemucatan dari pigmen rumput laut dan pada akhirnya akan mengalami kematian, sekitar 30\% masih hidup namun kondisinya kurang sehat. Demikian juga pada konsentrasi 1,2\% eksplan mengalami dehidrasi, kemudian terjadi 


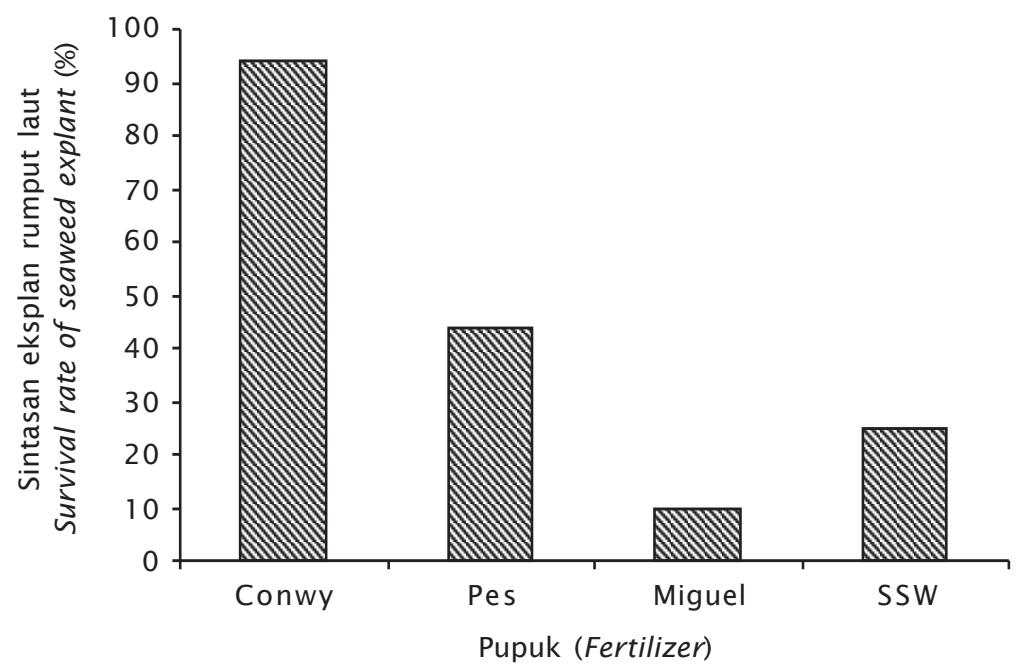

Gambar 1. Sintasan eksplan yang dikultur pada media dengan pupuk yang berbeda

Figure 1. Survival rate of seaweed explant at culture medium with different fertilizer

pemucatan dan akhirnya juga mengalami kematian.

Eksplan rumput laut yang kondisinya stabil baik pigmen maupun tallusnya yaitu pada media dengan kepadatan $0,8 \%$ hal ini kemungkinan disebabkan karena nutrien yang ada pada media mudah diserap dan dimanfaatkan oleh rumput laut (Gambar 2).

Intensitas cahaya dibutuhkan dalam pertumbuhan dan sintasan dari eksplan rumput (Amini et al., 1995), terutama dalam proses fotosintesis dan induksi kalus hingga

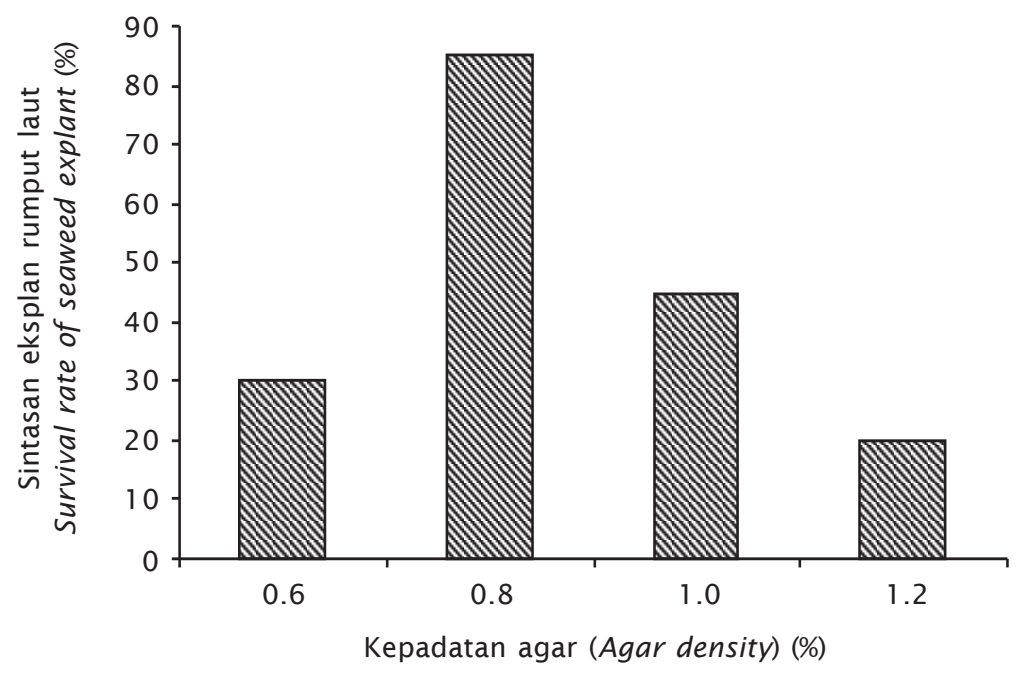

Gambar 2. Sintasan eksplan rumput laut yang dikultur pada media Conwy dengan kepadatan agar yang berbeda

Figure 2. Survival rate of seaweed explant on Conwy medium with different agar densities 


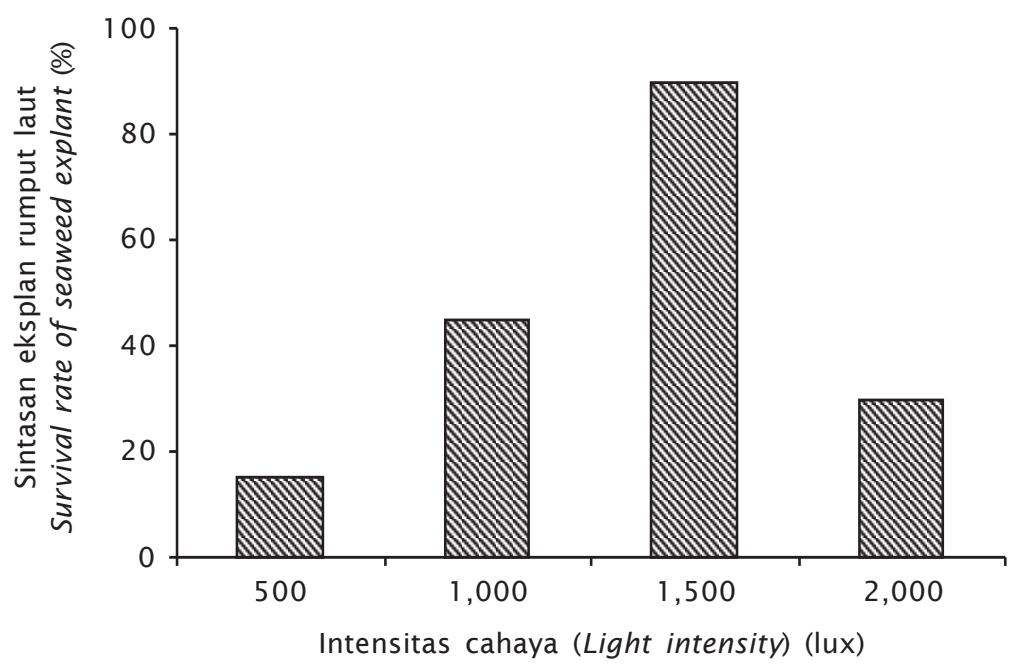

Gambar 3. Sintasan eksplan rumput laut yang dikultur pada media Conwy dengan intensitas cahaya yang berbeda

Figure 3. Survival rate of seaweed explant on Conwy medium with different light intensities

membentuk embrio. Hasil pengamatan dari intensitas cahaya mulai dari 500-2.000 lux dengan interval 500 lux memperlihatkan pertumbuhan dan sintasan yang paling baik adalah pada intensitas cahaya 1.500 lux. Pada 500 dan 1.000 lux, pertumbuhan dan induksi kalus tidak terjadi, tallus rumput laut berubah menjadi pucat dan transparan kemudian berangsur-angsur mati. Sedangkan pada intensitas cahaya di atas 1.500 lux memperlihatkan adanya penguapan pada media dan dehidrasi pada eksplan sehingga menjadi kering dan akhirnya mati (Gambar $3)$.

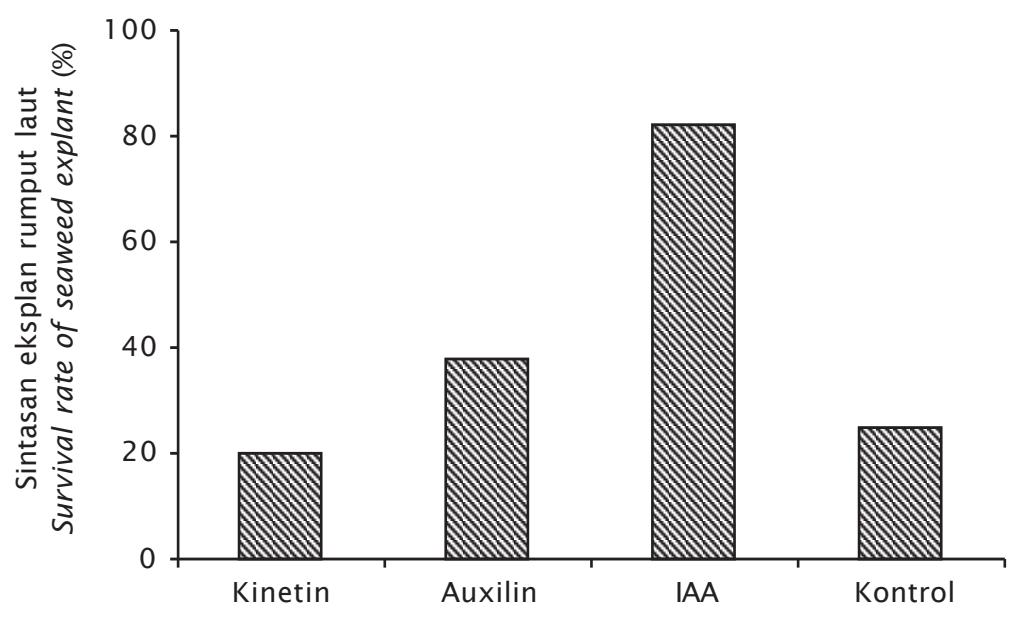

Hormon perangsang tumbuh (Growth hormon)

Gambar 4. Sintasan eksplan rumput laut yang dikultur pada media Conwy dengan hormon perangsang tumbuh yang berbeda

Figure 4. Survival rate of seaweed explant on Conwy medium with different growth hormones 
Pemberian hormon perangsang tumbuh pada media kultur, memacu terjadinya induksi kalus dan embrio pada rumput laut membentuk filamen, NAA, dan BAP (Benzil amino purin), telah digunakan untuk memacu pertumbuhan dan pembentukan embrio rumput laut (Reddy et al., 2003). Hasil pengamatan dari pemberian hormon Auxilin, IAA, dan Kinetin memperlihatkan pertumbuhan dan sintasan yang berbeda. Sintasan eksplan rumput laut yang diperkaya dengan IAA memperlihatkan nilai yang paling tinggi (84\%) dibandingkan dengan Auxilin, Kinetin, dan kontrol tanpa pemberian hormon (Gambar 4). IAA dan auxilin merupakan hormon tanaman yang termasuk golongan auxin, sedangkan kinetin termasuk golongan sitokinin. Kedua golongan hormon tersebut dibedakan dari fungsinya yaitu pada golongan sitokinin dapat mengatur proses fisiologi tumbuhan antara lain berpengaruh terhadap sintesa protein dan mengatur aktivitas enzim walaupun dengan konsentrasi rendah. Sedangkan pada golongan auxin seperti IAA dan auxilin berperan didalam pembelahan sel pada jaringan, diferensiasi unsur-unsur trakheal dan diferensiasi sel sewaktu membentang (Hendaryono et al., 1994). Pada induksi kalus dan pembentukan embrio rumput laut $K$. alvarezii, pemberian IAA memberikan sintasan dan pertumbuhan yang optimum pada proses embriogenesis di dalam media kultur diferensiasi.
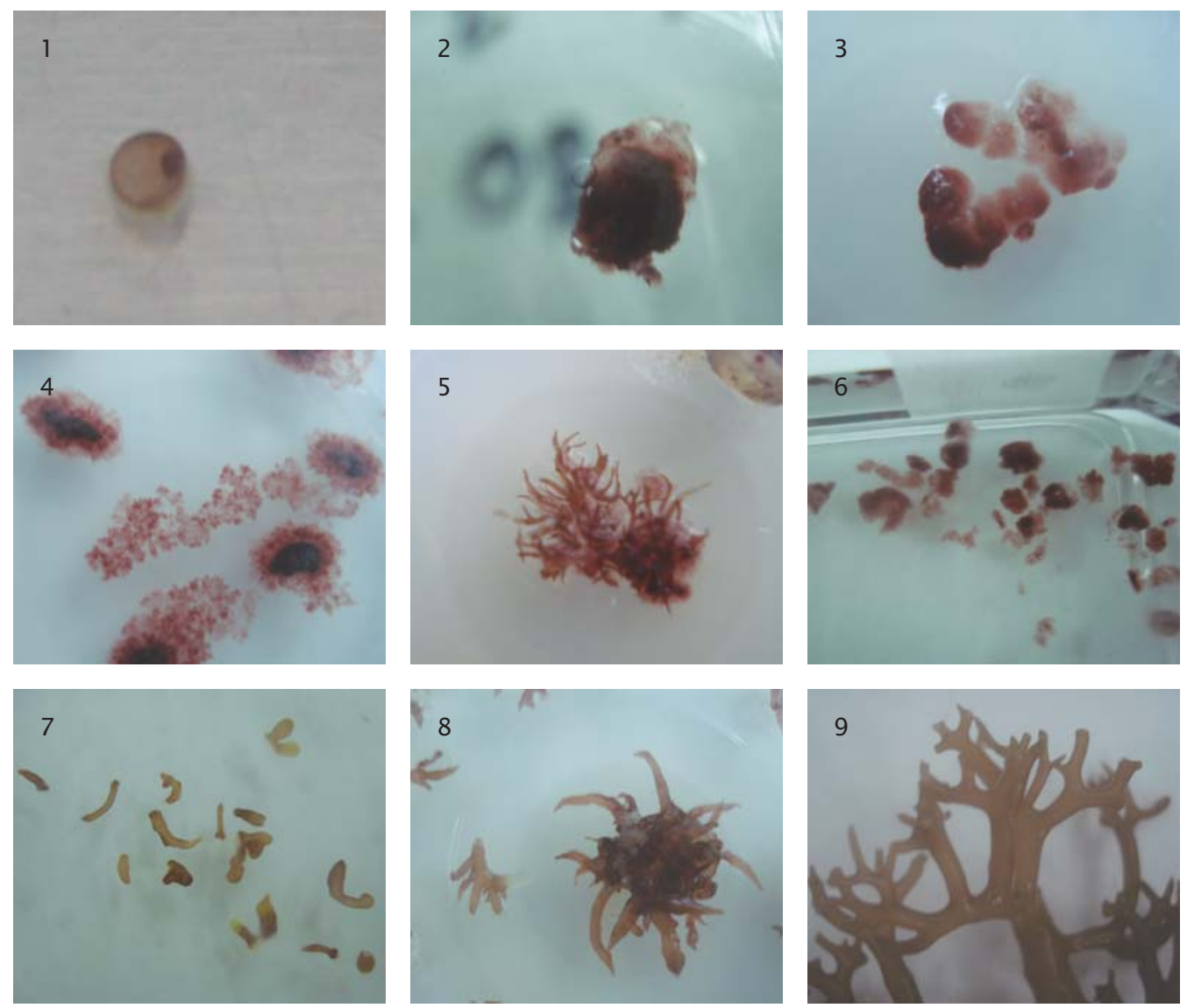

Gambar 5. Induksi kalus, sub kultur dan pembentukan embrio dengan penambahan hormon perangsang tumbuh (1. induksi kalus, 2. filamen, 3-4. Sub kultur filament, 5-6. embrio, 7-8. anakan, 9. RL dewasa)

Figure 5. Callus induction, sub culture and embryo development with growth hormon (1. callus induction, 2. filament, 3-4. sub culture; filament, 5-6. embryo, 7-8. young seaweed, 9. adult seaweed) 
Konsentrasi IAA yang digunakan berkisar antara 0,4 hingga $1,0 \mathrm{mg} / \mathrm{L}$ dan yang memberikan pertumbuhan paling baik yaitu pada konsentrasi 0,4 mg/L. Pada konsentrasi yang lebih tinggi memperlihatkan pertumbuhan yang semakin menurun. Hal ini disebabkan karena kebutuhan hormon pertumbuhan IAA pada rumput laut relatif kecil maka dengan peningkatan konsentrasi, eksplan rumput laut mengalami degradasi, dan menyebabkan kematian. Sehingga pada induksi kalus rumput laut $K$. alvarezii konsentrasi $0,4 \mathrm{mg} / \mathrm{L}$ sudah dapat memenuhi kebutuhan untuk diferensiasi jaringan, sedangkan pada konsentrasi yang lebih tinggi dapat menyebabkan terjadinya peracunan pada jaringan yang dapat menyebabkan kematian (Hendaryono et al., 1994).

Induksi kalus terbentuk melalui penebalan pada dinding tallus terutama pada bagian yang memiliki pigmen. Filamen yang terbentuk semakin banyak biasanya hingga menutupi eksplan pada bagian atas atau pada bagian irisan. Embrio dapat terbentuk dari filamenfilamen tersebut dan membentuk anakan yang sifat dan karakternya sama dengan induknya (Reddy et al., 2003).

Perkembangan dan sub kultur serta pembentukan embrio rumput laut Kappaphycus alvarezii pada pemeliharaan secara in vitro dapat dilihat pada Gambar 5.

\section{KESIMPULAN}

1. Media kultur yang paling baik untuk induksi kalus pada rumput laut K. alvarezii adalah media kultur yang diperkaya dengan pupuk Conwy

2. Kepadatan media kultur yang paling baik untuk pemeliharaan embrio adalah $0,8 \%$

3. Intensitas cahaya yang paling optimal pada pemeliharaan embrio adalah pada 1.500 lux

4. Hormon perangsang tumbuh yang paling baik pada rumput laut $K$. alvarezii adalah IAA dengan konsentrasi $0,4 \mathrm{mg} / \mathrm{L}$

\section{DAFTAR ACUAN}

Amini, S., Amin, M., \& Parenrengi, A. 1995. Penelitian kultur jaringan rumput laut,
Kappaphycus alvarezii secara vegetatif. Laporan hasil penelitian ARMP Balitkandita, Maros.

Damayanti, D., Sudarsono, Mariska, I., \& Herman, M. 2007. Regenerasi pepaya melalui kultur in vitro. Jurnal Agro Biogen, 3(2): 49-54.

Hendaryono, D.P.S \& A. Wijayani. 1994. Teknik kultur jaringan. Pengenalan dan Petunjuk Perbanyakan Tanaman Secara VegetatifModern. Kanisius Jogyakarta, $139 \mathrm{hlm}$.

Huang, W. \& Fujita, Y. 1997. Callus induction and thallus regeneration of the red alga Meristotheca papulosa (Rhodophyta, Gigartinales). Bot. Mar., 40: 55-61.

Liao, I.C., Su, H.M., \&J.H. Lin. 1983. Larval foods for penaeid prawns. In Mc Vey, J.P. and J.R. Moore (Eds.). CRC Handbook of Mariculture, Crustacean Aquaculture volume I, CRC Press Inc. Boca Raton, Florida, p. 43-69.

Parenrengi, A., Sulaeman, Suryati, E., \& Tenriulo, A. 2004. Variasi genetika rumput laut Kappaphycus alvarezii yang dibudidayakan di Sulawesi Selatan. Laporan hasil penelitian Balai Riset Perikanan Budidaya Air Payau, 17 hlm.

Polne-Fuller, M. \& Gibor, A. 1984. Developmental studies in Porphyra. I. Blade differentiation in Porphyra perforata as expressed by morphology, enzymatic digestion and protoplast regeneration. J. Phycol., 20: 60916.

Reddy, C.R.K., Raja Krishna Kumar, G., Siddhanta, A.K., \& Tewari, A. 2003. In Vitro Somatic Embriogenesis and Regeneration of Somatic Embryos from Pigmented Callus of Kappaphycus alvarezii (Doty) Doty (Rhodophyta, Gigartinales). J. Phycol., 39: 610-616.

Suryati, Sulaeman, Dalfiah, A., \& Pasande, R. 2002. Teknik Kultur Jaringan Rumput Laut Eucheuma sp. dalam Rangka Penyediaan Benih pada Budidaya. Seminar Nasional Rumput Laut dan Mini Simposium Mikroalgae dan Kongres Ikatan Fikologi Indonesia, 8 pp.

Suryati, E., Rosmiati, dan Tenriulo, V. 2007. Kultur jaringan rumput laut (Gracillaria sp.) dari sumber tallus yang berbeda lokasi. Jurnal Riset Akuakultur, 2(2): 143-147. 